\title{
PENGARUH ECONOMIC VALUE ADDED DAN MARKET VALUE ADDED TERHADAP RETURN SAHAM PADA PERUSAHAAN MANUFAKTUR YANG TERDAFTAR DI BURSA EFEK INDONESIA
}

\author{
ESLI SILALAHI ${ }^{1}$ \\ MEIYANTI MANULLANG ${ }^{2}$ \\ ${ }^{1,2}$ Fakultas Ekonomi Program Studi Akuntansi Universitas Katolik Santo Thomas \\ esli2silalahi@gmail.com, meiyanti@gmail.com
}

\begin{abstract}
ABSTRAK
Penelitian ini bertujuan untuk mengetahui pengaruh Economic Value Added (EVA) dan Market Value Added (MVA) terhadap Return Saham pada perusahaan manufaktur yang terdaftar di Bursa Efek Indonesia. Metode pengumpulan data yang digunakan adalah tehnik dokumentasi dengan memperoleh data laporan keuangan perusahaan, yang dapat diakses melalui www.idx.co.id.Metode analisis yang digunakan adalah analisis regresi linear berganda, dengan melakukan uji asumsi klasik yaitu: uji normalitas, uji multikolonieritas dan uji heteroskedastisitas, kemudian melakukan uji t dan uji $\mathrm{F}$ untuk menguji secara empiris pengaruh Economc Value Added (EVA) dan Market Value Added (MVA) terhadap Return Saham pada perusahaan manufaktur yang terdaftar di Bursa Efek Indonesia. Populasi dalam penelitian ini adalah seluruh perusahaan manufaktur yang terdaftar di Bursa Efek Indonesia periode 2014-2017 sebanyak 156 perusahaan. Teknik pengambilan sampel dengan metode purposive sampling, berdasarkan tujuan peneliti dengan menggunakan beberapa kriteria tertentu, total sampel diperoleh sebanyak 25 perusahaan. Hasil penelitian uji t menunjukkan bahwa: Economic Value Added (EVA) berpengaruh positif dan signifikan terhadap Return Saham ; Market Value Added (MVA) berpengaruh negatif dan signifikan terhadap Return Saham. Uji F menunjukkan Economic Value Added (EVA) dan Market Value Added (MVA) berpengaruh simultan dan signifikan terhadap Return Saham.
\end{abstract}

Kata Kunci: Economic Value Added (EVA), Market Value Added (MVA) dan Return Saham.

\section{PENDAHULUAN}

Pasar modal Indonesia dengan keterbatasan instrumen-instrumenya memungkinkan mobilisasi dana masih relatif terbatas jika dibandingkan dengan bursa-bursa dunia yang telah mapan, tetapi dapat menjadi wahana penting di luar perbankan untuk menyediakan dana yang diperlukan dunia usaha melalui penjualan saham dan obligasi serta derivatif. Dengan adanya mobilisasi dana yang tinggi dapat digunakan perusahaan untuk meningkatkan kinerjanya

Sejalan dengan semakin diminati pendanaan dari pasar modal, hal ini dapat membantu dalam era perdagangan bebas, lalu lintas keuangan internasional, dan keluar masuknya arus modal dan investasi. Kondisi tersebut mendorong percepatan pergerakan arus uang ( flow of fund) dan arus modal (flow of capital) melintasi batas negara menuju negara yang iklim investasinya menjanjikan penghasilan (expected rate of return) yang paling tinggi dengan resiko yang relatif sama atau lebih kecil.

Investor maupun calon investor dapat memperkirakan berapa tingkat pengembalian yang diharapkan (expected return) dan seberapa jauh kemungkinan hasil yang sebenarnya nanti akan menyimpang dari hasil yang diharapkan. Apabila kesempatan investasi mempunyai tingkat risiko yang lebih tinggi, maka investor akan mengisyaratkan tingkat keuntungan yang lebih tinggi. Dengan kata lain, semakin tinggi risiko suatu investasi maka akan semakin tinggi pula keuntungan (return) yang diisyaratkan oleh oleh investor (Jogiyanto, 2000).

Return saham adalah tingkat keuntungan yang dinikmati oleh pemodal atas suatu investasi yang dilakukannya (Robert Ang,2001). Dalam teori pasar modal, tingkat pengembalian yang diterima oleh seorang investor dari saham yang diperdagangkan di pasar modal biasa diistilahkan dengan return. Return dapat berupa return realisasi yang sudah terjadi atau return ekspektasi yang belum terjadi tetapi yang diharapkan akan terjadi di masa mendatang. Return realisasi (realized return) merupakan return yang telah terjadi dan di hitung berdasarkan data histori dan return realisasi digunakan sebagai salah satu pengukur kinerja dari perusahaan sebagai dasar penentu return ekspektasi (expected return) dan resiko di masa mendatang. 
Salah satu analisis untuk perencanaan dan pengendalian keuangan yang baik adalah dengan melakukan analisis rasio keuangan. Rasio keuangan merupakan fundamental perusahaan, dimana rasio keuangan merupakan perbandingan antara dua elemen laporan keuangan pada periode tertentu (Brigham 2009). Analisis laporan keuangan adalah hubungan antara suatu angka dalam laporan keuangan dengan angka lain yang mempunyai makna atau dapat menjelaskan arah perubahan suatu fenomena (Soemarsono 2005). Laporan keuangan tidak hanya sebagai alat penguji saja tetapi juga sebagai dasar untuk dapat menentukan atau menilai posisi keuangan perusahaan tersebut, dimana dengan hasil analisa tersebut pihak-pihak yang berkepentingan mengambil suatu keputusan, serta hasil-hasil yang telah dicapai oleh perusahaan tersebut perlu adanya laporan keuangan dari perusahaan yang bersangkutan.

Dari laporan keuangan dapat memberikan informasi kepada investor maupun calon investor, sehingga mereka dapat menganalisis kinerja perusahaan emiten. Informasi tersebut bermanfaat bagi sebagian besar pemakai dalam pengambilan keputusan ekonomi, sehingga para investor dapat melakukan pengukuran kinerja perusahaan melalui analisis terhadap laporan keuangan yang disajikan oleh perusahaan. Dari analisis laporan keuangan, maka dapat diketahui kondisi perusahaan tersebut.

Kinerja perusahaan dapat digunakan untuk mengukur keberhasilan perusahaan dalam mencapai tujuan perusahaan. Kinerja perusahaan adalah hasil atau manfaat operasional perusahaan atas dana yang digunakan perusahaan tersebut. Penilaian kinerja operasional perusahaan membutuhkan suatu pengukuran terhadap kinerja keuangan perusahaan dimana pengukuran kinerja keuangan perusahaan secara umum dilakukan melalui analisa rasio keuangan yang disebut dengan pengukuran kinerja keuangan dengan pendekatan konvensional.

Pendekatan konvensional ini seringkali mendapat kendala bahwa dalam pengukurannya mengabaikan adanya biaya modal sehingga sulit untuk mengetahui apakah suatu perusahaan telah memberikan nilai atas dana yang diinvestasikan oleh perusahaan tersebut. Untuk mengatasi hal tersebut kemudian muncul konsep penilaian kinerja keuangan perusahaan yang baru dengan pendekatan yang lebih objektif dan mampu menghubungkan kepentingan manajemen maupun investor yaitu dengan konsep economic value added atau nilai tambah ekonomis yang sering disebut dengan EVA.

Menurut Kasmir (2010) rasio keuangan adalah kegiatan membandingkan angka-angka yang ada dalam laporan keuangan dengan cara membagi satu angka dengan angka lainnya. Meskipun analisis rasio keuangan digunakan oleh investor sebagai alat pengukur konvensional, analisis rasio tersebut mempunyai kelemahan utama, yaitu mengabaikan adanya biaya modal sehingga sulit untuk mengetahui apakah suatu perusahaan telah berhasil menciptakan suatu nilai atau belum. Oleh karena itu, pada tahun 1989, Konsultan Stern Steward Management Service di Amerika Serikat memperkenalkan konsep Economic Value Added (EVA) dan Market Value Added (MVA) sebagai alat ukur kinerja keuangan dan pasar untuk mengatasi kelemahan dari rasio keuangan, (Young,O'Byerne 2001)

Variabel pertama yang dianggap dapat menjadi penjelas return saham adalah economic value added (EVA). Menurut Wijaya Tunggal (2011) Economic Value Added pada dasarnya adalah laba yang tertinggal setelah dikurangi dengan biaya modal yang di investasikan. Menurut Brigham dan Houston (2009), EVA menyajikan suatu ukuran yang baik mengenai sampai sejauh mana perusahaan telah memberikan tambahan pada nilai pemegang saham. Dengan kata lain apabila manajemen perusahaan memusatkan diri pada EVA, maka mereka akan mengambil keputusan-keputusan terkait keuangan yang konsisten dengan tujuan memaksimalkan kemakmuran atau kekayaan pemegang saham. Economic value added (EVA) mengukur seberapa efisien perusahaan menggunakan modalnya untuk menciptakan nilai tambah ekonomis.

Nilai tambah ekonomis tercipta jika perusahaan menghasilkan return on total capital yang melebihi cost of capital. Economic value added (EVA) positif berarti perusahaan memeroleh laba karena tingkat pengembalian melebihi biaya modalnya, sehingga perusahaan yang memperoleh laba akan membagikan sebagian labanya sebagai dividen kepada investor. Semakin tinggi laba yang diperoleh perusahaan, maka semakin tinggi pula dividen yang diperoleh investor. Semakin tinggi capital gain dan dividen, maka Return saham juga akan semakin tinggi. Perusahaan yang memiliki nilai Economic value added (EVA) tinggi dapat lebih menarik investor untuk berinvestasi di perusahaan tersebut. Semakin tinggi nilai Economic value added (EVA) mencerminkan laba perusahaan yang tinggi. 
Variabel kedua yang dianggap dapat menjadi penjelas return saham adalah Market Value Added (MVA). Market value added (MVA) adalah perbedaan antara nilai pasar ekuitas suatu perusahaan dengan nilai buku seperti yang disajikan dalam neraca, nilai pasar dihitung dengan mengalikan harga saham dengan jumlah saham yang beredar (Brigham 2010). Pengukuran MVA menilai dampak tindakan manajer atas kemakmuran pemegang sahamnya sejak perusahaan tersebut berdiri. Kekayaan pemegang saham akan menjadi maksimal dengan memaksimalkan perbedaan antara nilai pasar ekuitas perusahaan dan jumlah modal ekuitas yang di investasikan investor, perbedaan inilah yang disebut market value added (MVA), (Brigham 2010). Semakin tinggi MVA, semakin baik kinerja perusahaan,

Dodd dan Chen (1996) menunjukkan pengaruh positif EVA terhadap return saham namun EVA bukan satu-satunya pengukur kinerja yang dapat dikaitkan dengan return saham. Lebih jauh, Dodd dan Chen (1996) menemukan bahwa ROA masih dianggap lebih baik dan berkorelasi sedikit lebih tinggi daripada EVA. Bacidore et al (1997) menunjukkan hasil yang kontradiktif, dimana Bacidore et al. (1997) menemukan EVA sebagai pengukur kinerja yang paling signifikan mempengaruhi return saham daripada ukuran kinerja keuangan konvensional, seperti ROA.

Rousana (1997) dalam penelitiannya menunjukkan bahwa EVA tidak berpengaruh signifikan terhadap return saham perusahaan. Penelitian tersebut didukung oleh Dewanto (1998) yang menunjukkan hasil bahwa EVA tidak berpengaruh signifikan terhadap harga atau return saham. Kedua hasil penelitian tersebut juga didukung oleh Sartono dan Setiawan (1999) menunjukkan bahwa EVA tidak signifikan berhubungan dengan abnormal return .

Hal ini juga di dukung penelitian Iman Ghozali dan Irwansyah (2002) meneliti analisis pengaruh kinerja keuangan perusahaan dengan alat ukur economiv value added (EVA), Market value added (MVA) dan retun on asset (ROA) pada saham manufaktur. Hasil penelitian menyimpulkan bahwa EVA, ROA tidak berpengaruh signifikan terhadap return saham, sedangkan MVA berpengaruh signifikan terhadap return saham. Berbeda Lehn dan Makhija dalam Kartini dan Hermawan (2008) dimana hasil penelitiannya menjelaskan bahwa EVA memiliki pengaruh yang positif dan signifikan terhadap return saham.

Berdasarkan uraian diatas perlu dilakukn analisis lebih lanjut tentang pengaruh Economic Value Added (EVA) dan Market Value Added (MVA) terhadap return saham pada perusahaan manufactur yang terdaftar di Bursa Efek Indonesia.

\section{Perumusan Masalah}

1. Apakah Economic Value Added (EVA) berpengaruh secara parsial dan signifikan terhadap Return Saham pada Perusahaan Manufaktur yang terdaftar di Bursa Efek Indonesia?

2. Apakah Market Value Added (MVA) berpengaruh secara parsial dan signifikan terhadap Return Saham pada Perusahaan Manufaktur yang terdaftar di Bursa Efek Indonesia?

3. Apakah Economic Value Added (EVA) dan Market Value Added (MVA) berpengaruh secara simultan dan signifikan terhadap Return Saham pada perusahaan Manufaktur yang terdaftar di Bursa Efek Indonesia?

\section{Tujuan Penelitian}

Adapun tujuan dalam penelitian ini adalah sebagai berikut:

1. Untuk mengetahui pengaruh Economic Value Added (EVA) secara parsial dan signifikan terhadap Return Saham pada perusahaan Manufaktur yang terdaftar di Bursa Efek Indonesia.

2. Untuk mengetahui pengaruh Market Value Added (MVA) secara parsial dan signifikan terhadap Return Saham pada perusahaan Manufaktur yang terdaftar di Bursa Efek Indonesia.

3. Untuk mengetahui pengaruh Economic Value Added (EVA) dan Market Value Added (MVA) secara simultan dan signifikan terhadap Return Saham pada perusahaan Manufaktur yang terdaftar di Bursa Efek Indonesia.

\section{Tinjauan Pustaka}

\section{Economic Value Added (EVA)}

EVA dipopulerkan oleh Stern Steward Management Service yang merupakan perusahaan konsultan dari Amerika Serikat. Dan ukuran kinerja ini pertama kali diperkenalkan oleh George Bennet Steward III dan Joel M Stern yang merupakan analis keuangan Stern Steward. Economiv value 
Added (EVA) adalah nilai yang ditambahkan oleh manajemen kepada pemegang saham selama satu tahun tertentu (Brigham dan Houston, 2009). Menurut Tandelilin dalam (Sihaloho dkk, 2017).EVA adalah ukuran keberhasilan manajemen perusahaan dalam meningkatkan nilai tambah (value added) bagi perusahaan. Asumsinya adalah bahwa jika kinerja manajemen baik/efektif (dilihat dari besarnya nilai tambah yang diberikan), maka akan tercermin pada peningkatan harga saham perusahaan. Jika pengembalian suatu proyek melebihi yang diminta pasar keuangan, ini dikatakan menerima pengembalian berlebih. Pengembalian ini, seperti yang kita artikan, menunjukkan penciptaan nilai, (Van Horne 1999). EVA sebagai alat komunikasi yang efektif, baik untuk penciptaan nilai yang dapat dijangkau oleh manajer lini yang akhirnya mendorong kinerja perusahaan untuk berhubungan dengan pasar modal, Young,O'Byerne (2001)

Berdasarkan pengertian di atas maka dapat disimpulkan, bahwa EVA ditentukan oleh dua hal, yaitu: (1). Keuntungan bersih operasi setelah pajak dan (2).Tingkat biaya modal. Laba operasi setelah pajak menggambarkan hasil penciptaan nilai (value) di perusahaan, sedangkan biaya modal dapat diartikan sebagai pengorbanan yang dikeluarkan dalam penciptaan value tersebut. Eva menyajikan suatu ukuran yang baik mengenai sampai sejauh mana perusahaan telah memberikan tambahan pada nilai pemegang saham. Oleh karena itu, jika manajer berfokus pada EVA, hal ini akan dapat membantu memastikan bahwa mereka telah menjalankan operasi dengan cara yang konsisten dengan tujuan untuk memaksimalkan kekayaan pemegang saham (Brigham dan Houston, 2009).

Penilaian EVA dapat dinyatakan sebagai berikut: Young,O'Byerne (2001)

a. Apabila EVA > 0, berarti nilai EVA positif yang menunjukkan telah terjadi proses nilai tambah pada perusahaan.

b. Apabila EVA = 0 menunjukkan posisi impas atau Break Event Point.

c. Apabila EVA < 0, yang berarti EVA negatif menunjukkan tidak terjadi proses nilai tambah.

Konsep Economic Value Added (EVA) mengukur nilai tambah dengan cara mengurangi biaya modal (cost of capital) yang timbul akibat investasi yang dilakukan oleh perusahaan. Economic Value Added (EVA) yang positif menandakan perusahaan berhasil menciptakan nilai bagi pemilik modal Karena perusahaan mampu menghasilkan tingkat pengembalian yang melebihi tingkat modalnya. Hal ini sejalan dengan tujuan untuk memaksimumkan nilai perusahaan. Sebaliknya, economic value added (EVA) yang negatif menunjukkan bahwa nilai perusahaan menurun, karena tingkat pengembalian lebih rendah dari biaya modal. Economic value added (EVA) merupakan selisih antara net operating after tax (NOPAT) dengan biaya modal, yang dapat diformulasikan sebagai berikut:
EVA = NOPAT - Biaya Modal
EVA $=$ NOPAT $-($ WACC X Capital $)$
Keterangan :
EVA = Economic Value Added
NOPAT = Net Operating Profit After Tax (Laba operasi bersih setelah pajak)
Capital = Modal yang di investasikan
WACC $=$ Weighted Averege Cost of Capital (Biaya modal rata-rata tertimbang)

Langkah-langkah dalam menentukan EVA sebagai berikut:

1. Menghitung Net Operating Profit After Tax (NOPAT)

NOPAT adalah laba yang akan dihasilkan oleh sebuah perusahaan jika perusahaan tidak memiliki utang maupun aktiva non-operasi, (Brigham dan Houston 2009), NOPAT dapat dihitung dengan formula sebagai berikut:

NOPAT $=$ EBIT $(1-$ Tax $)$

Keterangan:

EBIT : Earnings Before Interest and Tax atau laba sebelum bunga dan pajak

Tax : Tarif pajak

2. Menghitung biaya modal

Biaya modal suatu perusahaan bergantung tidak hanya pada biaya hutang dan pembiayaan ekuitas, tetapi juga seberapa banyak dari masing-masing itu dimiliki oleh struktur modal. Hubungan ini digabungkan dalam biaya modal rata-rata tertimbang (weighted average cost of capital) atau WACC, karena perusahaan memiliki struktur modal optimal yang merupakan perpaduan antara hutang saham preferen.

Biaya Modal dapat diformulasikan sebagai berikut : 
Biaya Modal = WACC X Capital

3. Menghitung biaya modal rata-rata tertimbang (WACC)

Biaya modal rata-rata tertimbang (Weighted Average Cost of Capital) atau WACC mencerminkan rata-rata biaya modal di masa yang akan datang yang diharapkan, maka untuk perhitungan WACC perlu dipertimbangkan biaya modal setiap komponen, yaitu biaya modal sendiri dan biaya pinjaman,

Biaya modal adalah biaya (bunga) pinjaman dan biaya ekuitas yang dimanfaatkan untuk menghasilkan NOPAT tersebut, dan dihitung secara rata-rata tertimbang (Weighted Average Of cost). Komponen modal (capital components) adalah salah satu jenis modal yang digunakan perusahaan untuk mendapatkan uang, Brigham (2010), komponem biaya modal sebagai berikut

- Biaya Hutang, digunakan untuk menghitung biaya modal rata-rata tertimbang yang dihitung dengan rumus

$k d=\frac{I+(N-N b) / n}{(N b+N) / 2}$

Dimana

$\mathrm{kd}=$ biaya modal hutang obligasi suku bunga hutang

I = Bunga hutang jangka panjang

$\mathrm{N}$ = Harga nominal obligasi

$\mathrm{Nb}=$ Nilai bersih penjualan obligasi

$\mathrm{n}=$ Umur obligasi

- Biaya ekuitas (ks) adalah tingkat pengembalian yang diperlukan pemegang saham atas saham biasa perusahaan.

Ada beberapa cara yang digunakan untuk menghitung biaya ekuitas (ks) Brigham (2010) antara lain : (1) Capital asset pricing model (CAPM), (2) Bond yield plus equity risk premium atau hasil obligasi ditambah premi risiko modal, (3). Realized investor yield atau hasil nyata yang diterima investor, dan (4). Growth deviden model atau Model pertumbuhan deviden.

1. Capital Asset Pricing Model atau CAPM.

$k s=R_{f}+\left(R_{m}-R_{f}\right) \beta i$

Dimana:

Ks = Biaya ekuitas

$\mathrm{Rf}=$ tingkat return bebas risiko

$\mathrm{Rm}=$ return portfolio pasar yang diharapkan

$\beta=$ koefisien beta saham ke-I

$\beta i=\frac{\operatorname{COV}(R i, R m)}{\operatorname{VAR}(R m)}$

2. Bond yield plus equity risk premium

Perhitungan hasil pengembalian atas modal yang dibutuhkan dengan menggunakan metode CAPM menghasilkan premi atas suku bunga bebas risiko yang digunakan dengan menggunakan surat-surat berharga yang dikeluarkan pemerintah. Metode ini melibatkan premi risiko, tetapi premi yang diperkirakan dalam metode ini adalah premi atas biaya hutang jangka panjang perusahaan.Untuk mencari Bond yield plus risk premium (Ks)

$\mathrm{Ks}=$ Hasil obligasi + Premi risiko

3. Realized investor yield

Hasil nyata yang diterima investor adalah hasil deviden rata-rata ditambah keuntungan modal rata-rata. Metode ini menyajikan apa yang diharapkan oleh investor sebagai hasil pengembalian atas saham biasa perusahaan

4. Growth deviden model

Hasil pengembalian atas modal yang diharapkan dapat diperoleh melalui persamaan penilaian deviden.

$$
k_{s}=\frac{d_{1}}{p_{o}}+g
$$

ks : Biaya saham biasa

d1 : deviden per saham. 
Po : Harga saham biasa

$\mathrm{g}$ : Tingkat pertumbuhan deviden

\section{Market Value Added (MVA)}

Market value adde (MVA) merupakan pengukuran yang membedakan antara nilai pasar dari sebuah perusahaan dengan kontribusi modal yang diberikan oleh para pemilik dan kreditor. MVA merupakan penentu pengukuran penciptaan kesejahteraan para pemegang saham. MVA diperoleh dengan mengalikan selisih antara harga saham dan nilai buku per lembar saham dengan jumlah saham yang dikeluarkan.

Menurut Brigham dan Houston (2010), Market Value Added (MVA) adalah perbedaan antara nilai pasar saham perusahaan dengan jumlah ekuitas modal investor yang telah diberikan. Kekayaan atau kesejahteraan pemilik perusahaan (pemegang saham) akan bertambah bila MVA bertambah. Tujuan utama sebagian besar perusahaan adalah memaksimalkan kekayaan pemegang saham, tujuan ini jelas memihak pada keuntungan pemegang saham, akan tetapi juga harus memastikan sumber daya yang terbatas telah dialokasikan secara efisien yang menguntungkan perekonomian. Kekayaan pemegang saham akan menjadi maksimal dengan memaksimalkan perbedaan antara nilai pasar ekuitas perusahaan dan modal ekuitas yang diinvestasikan investor. Market Value Added (MVA) adalah perbedaan antara nilai pasar saham perusahaan dengan jumlah ekuitas modal investor yang telah diberikan (Brigham, 2009).

MVA =Nilai Pasar - Modal Yang Di Investasikan

Jika Market Value Added (MVA) > 0, bernilai positif, perusahaan berhasil meningkatkan nilai modal yang telah diinvestasikan oleh penyandang dana, dan jika Market Value Added (MVA) $<0$, bernilai negatif, perusahaan tidak berhasil meningkatkan nilai modal yang telah diinvestasikan oleh penyandang dana, (Young dan O’Byrne, 2001).

\section{Return Saham}

Return merupakan hasil yang diperoleh dari suatu investasi. Menurut Jogiyanto (2000), return saham dibedakan menjadi dua yaitu return realisasi (realized return) dan return ekspektasi (expected return). Return realisasi merupakan return yang sudah terjadi yang dihitung berdasarkan data historis. Return realisasi ini penting dalam mengukur kinerja perusahaan dan sebagai dasar penentuan return dan risiko dimasa mendatang. Return saham yaitu merupakan penghasilan yang diperoleh investor atas investasi yang ditanamkan dalam bentuk saham, dimana return saham dapat diukur sebagai berikut :

$R t S=\frac{D_{t}+\left(P_{t}-P_{t-1}\right)}{P_{t-1}}$

$R_{t S=\text { Return saham }}$

$P_{\text {it }}=$ Harga saham penutupan ke i pada periode $\mathrm{t}$

$P_{\text {it-1 }}=$ Harga saham penutupan ke i pada periode $\mathrm{t}-1$

Dt $=$ Deviden pada periode $\mathrm{t}$

\section{Pengaruh Economic Value Added (EVA) terhadap Return Saham}

Return Saham yang terdiri dari capital gain dan dividen merupakan tujuan para investor melakukan investasi saham. Return Saham dapat dijadikan sebagai salah satu indikator untuk tujuan maksimisasi kemakmuran pemegang saham. economic value added (EVA) merupakan salah satu alat pengukur kinerja yang menunjukkan suatu ukuran yang baik mengenai sampai sejauh mana perusahaan telah memberikan tambahan nilai pada pemegang saham. Nilai tambah ini terjadi apabila perusahaan memperoleh laba lebih besar dari cost of capital perusahaan.

Semakin tinggi nilai EVA mencerminkan laba perusahaan yang semakin tinggi pula. Hal ini akan menarik investor untuk berinvestasi di perusahaan tersebut. Dengan bertambahnya jumlah investor, maka harga saham akan naik yang kemudian diikuti dengan meningkatnya Return Saham melalui capital gain. Dengan meningkatnya laba, maka laba yang dibagikan kepada para pemegang saham dalam bentuk dividen juga akan meningkat. Semakin tinggi capital gain dan dividen, maka Return Saham juga akan semakin tinggi. Hal ini menunjukkan bahwa EVA berpengaruh terhadap 


\section{Return Saham.}

\section{Pengaruh Market Value Added (MVA) terhadap Return Saham}

Market Value Added (MVA) merupakan jumlah nilai total perusahaan yang telah terapresiasi lebih besar dari jumlah nilai uang yang diinvestasikan ke dalam perusahaan oleh para pemegang saham. Perusahaan dengan kinerja baik ditunjukkan dengan MVA yang bernilai positif. Sedangkan MVA yang bernilai negatif menunjukkan berkurangnya nilai modal pemegang saham.

Semakin tinggi nilai MVA maka harga saham juga semakin tinggi, sehingga Return Saham akan semakin naik. Dengan demikian dapat dikatakan bahwa kekayaan pemegang saham akan bertambah. Apabila nilai MVA bertambah melalui meningkatnya capital gain dan harga saham maka return saham akan semakin meningkat. Hal tersebut menujukkan adanya pengaruh market value added (MVA) terhadap return saham.

Berdasar konsep tersebut maka EVA dan MVA berhubungan positip dengan tingkat pengembalian (return) yang akan diterima oleh para pemegang saham, karena EVA yang semakin besar menunjukkan kinerja perusahaan semakin meningkat sehingga return saham juga meningkat; demikian pula MVA. Teori tersebut tidak sepenuhnya didukung oleh hasil-hasil penelitian yang menghubungkan EVA dan MVA dengan return saham.

Sebagaimana telah dikemukakan sebelumnya bahwa hasil-hasil penelitian yang menghubungkan EVA dan MVA dengan return saham menunjukkan bukti empiris yang berbeda-beda terutama hasil penelitian Bacidore et al (1997) dalam Sartono dan Setiawan (1999) dengan hasil penelitian Dodd dan Chen (1996). Perbedaan hasil penelitian tersebut terletak pada pentingnya EVA dan MVA sebagai prediktor terhadap return saham. Bacidore et al (1997) dalam Sartono dan Setiawan (1999) menemukan bahwa EVA dan MVA merupakan faktor yang dominan berhubungan positif dengan abnormal return.

\section{METODOLOGI PENELITIAN}

\section{Populasi dan Sampel}

Populasi dalam penelitian ini adalah seluruh perusahaan manufaktur yang terdaftar di Bursa Efek Indonesia pada tahun 2014 - 2017, sebanyak 156 perusahaan, sampel penelitian sebanyak 25 perusahaan manufaktur dimana penarikan sampel dengan metode purposive sampling yaitu berdasarkan kriteria dan tujuan penelitian. Kriteria sampel adalah sebagai berikut : (1). Perusahaan yang dipilih adalah perusahaan manufaktur yang terdaftar di Bursa Efek Indonesia selama periode pengamatan yang sahamnya aktif diperdagangkan di BEI; (2). Perusahaan manufaktur yang telah menerbitkan laporan keuangan yang lengkap yang telah diaudit pada selama periode pengamatan; (3). Perusahaan manufaktur yang memberikan return saham yang positif selama periode pengamatan; (4). Perusahaan manufaktur yang terdaftar di Bursa Efek Indonesia (BEI) yang membagikan dividen kepada para pemegang saham selama periode pengamatan

\section{Metode Pengumpulan Data}

Metode pengumpulan data yang digunakan dalam penelitian ini adalah tehnik Dokumentasi melalui data laporan keuangan perusahaan manufaktur yang terdaftar di Bursa Efek Indonesia yang dapat diakses melalui www.idx.co.id.

\section{Operasionalisasi variabel}

Variabel dependent adalah return saham (RtS) merupakan suatu penghasilan yang diperoleh investor atas investasi yang ditanamkan dalam bentuk saham.

$$
\begin{aligned}
& R t S=\frac{D_{t}+\left(P_{t}-P_{t-1}\right)}{P_{t-1}} \\
& \text { RtS = Return Saham } \\
& D_{t}=\text { Devidend yang dibayarkan pada periode } \mathrm{t} \\
& P_{t=} \text { Harga saham pada periode } \mathrm{t} \\
& P_{t-1}=\text { Harga saham pada periode } \mathrm{t}-1
\end{aligned}
$$

Variabel independent (EVA, MVA) 
Economic Value Added (EVA) adalah pengukur kinerja perusahaan yang melihat segi ekonomis dalam pengukuranya, yaitu dengan memperhatikan harapan-harapan pada pemilik modal (kreditur dan pemegang saham secara adil). Dimana Economic Value Added (EVA) menggunakan satuan rupiah (Rp) yang dihitung sebagai berikut

$\mathrm{EVA}=\mathrm{NOPAT}-($ WACC $\mathrm{X}$ Capital $)$

Market Value Added (MVA)

MVA (Market Value Added) adalah perbedaan antara nilai pasar saham perusahaan dengan jumlah ekuitas modal investor yang telah diberikan, (Brigham,2009). Dimana MVA (Market Value Added) dapat dihitung sebagai berikut

MVA $=($ Saham Beredar $)($ Harga Saham $)-$ Total Ekuitas Saham Biasa

\section{Tehnik analisis}

Tehnik analisis data yang digunakan adalah regresi linear berganda dengan model

$\boldsymbol{R t S}=\mathbf{a}+\boldsymbol{\beta} 1 \mathrm{EVA}+\boldsymbol{\beta} 2 \mathrm{MVA}+\boldsymbol{\varepsilon}$

RtS = Return Saham

a $\quad=$ Konstanta

EVA $=$ Economic Value Added

MVA = Market Value Added

$\beta 1,2=$ Koefisien regresi

$\varepsilon \quad=$ error term

\section{ANALISIS DAN PEMBAHASAN}

Sebelum pengujian hipotesis, dilakukan Uji Asumsi Klasik meliputi normalitas multikolinearitass dan heteroskedastisita. Dari hasil uji asumsi klasik variabel residual terdistribusi secara normal, nilai tolerance masing-masing variabel bebas memiliki nilai variance inflation factor (VIF) kurang dari 0,10 atau tidak ada satupun variabel bebas yang memiliki nilai VIF lebih dari 10, artinya tidak terdapat multikoloniaritas antar variable serta tidak terjadi heteroskedastisitas sehingga model regresi layak digunakan untuk memprediksi return saham berdasarkan masukan kedua variabel independen (EVA dan MVA). Tehnik analisis yang digunakan adalah regresi linear berganda dengan hasil penelitian ditunjukkan pada Tabel 1 .

Tabel 1 Hasil Analisis Regresi Berganda

\begin{tabular}{|c|c|c|c|c|}
\hline $\begin{array}{l}\text { Variabel } \\
\text { Independen } \quad \& \\
\text { Konstan }\end{array}$ & $\begin{array}{l}\text { Koefisien } \\
\text { regresi }\end{array}$ & $\begin{array}{l}\text { Standard of } \\
\text { Error }\end{array}$ & t. hitung & Signifinance \\
\hline EVA & 0,878 & 0,364 & 2,412 & 0,023 \\
\hline MVA & $-1,442$ & 0,287 & $-5,024$ & 0,000 \\
\hline Constant & 20,647 & 8,562 & 2,411 & 0,023 \\
\hline R Square & 0,774 & & & \\
\hline Adjusted R Square & 0,569 & & & \\
\hline F. Hitung & 20,172 & & & \\
\hline Signifinance &, $000^{\mathrm{a}}$ & & & \\
\hline
\end{tabular}

\section{Return saham $=20,647+0,878 E V A-1,442 M V A+e$}

Dari hasil persamaan tersebut di atas, dapat dijelaskan sebagai berikut:

1. Economic value added (EVA) mempunyai pengaruh positif terhadap return saham perusahaan manufaktur yang terdaftar di Bursa Efek Indonesia. Besarnya nilai koefisien regresi sebesar 0,878 artinya apabila Economic value added (EVA) naik sebesar $1 \%$ maka return saham naik sebesar 0,878. Sebaliknya apabila Economic value added (EVA) turun sebesar 1\% maka return saham juga turun sebesar 0,878

2. Market value added (MVA) mempunyai pengaruh negatif terhadap return saham perusahaan manufaktur yang terdaftar di Bursa Efek Indonesia. Besarnya nilai koefisien regresi sebesar 1,442 artinya apabila Market value added (MVA) naik sebesar 1\% maka return saham akan turun 1,442. Sebaliknya apabila Market value added (MVA) turun sebesar 1\% maka return 
saham akan naik sebesar 1,442

3. Nilai koefisien korelasi mengukur kereratan hubungan antara Economic value added (EVA) dan Market value added (MVA) dengan return saham sebesar 77,4 \%. Dari nilai koefisien korelasi tersebut dapat disimpulkan Economic value added (EVA) dan Market value added (MVA) mempunyai hubungan yang positif dan kuat dengan return saham.

4. Nilai koefisien determinasi mengukur proporsi variasi return saham dapat dijelaskan Economic value added (EVA) dan Market value added (MVA). Berdasarkan hasil pengujian di atas besarnya koefisien determinasi adalah 56,9\% artinya bahwa return saham dapat dijelaskan oleh variasi Economic value added (EVA) dan Market value added (MVA) sebesar 56,9\% dan selebihnya sebesar $43.1 \%$ dapat dijelaskan olek faktor lain yang tidak terliput dalam model penelitian ini seperti variabel faktor fundamental meliputi rasio keuangan.

\section{Pengujian Hipotesis}

Dalam penelitian ini pengujian hipotesis yang dilakukan adalah pengujian hipotesis secara parsial (uji t) dan pengujian hipotesis secara simultan (uji F). Berdasarkan uji t yang ditunjukkan pada Tabel 1. di atas dapat dijelaskan bahwa Economic value added (EVA) berpengaruh positif dan signifikan terhadap return saham perusahaan manufaktur yang terdaftar di Bursa Efek Indonesia, hal ini ditunjukkan dari nilai signifikan $<0,05$ atau t hitung $>$ t. table. Market value added (MVA) berpengaruh negative dan sinifikan terhadap return saham perusahaan manufaktur yang terdaftar di Bursa Efek Indonesia

Pengujian secara simultan: Economic value added (EVA dan Market value added (MVA) secara simultan berpengaruh signifikan terhadap return saham perusahaan manufaktur yang terdaftar di Bursa Efek Indonesia yang ditunjukkan F hitung > F table.

\section{PEMBAHASAN}

Berdasarkan hasil perhitungan yang ditunjukkan Tabel 1. menunjukkan nilai koefisien regresi 0,878 , artinya bahwa Economic Value Added (EVA) berpengaruh positif terhadap return saham. Apabila Economic Value Added (EVA) naik sebesar 1\% maka return saham akan naik sebesar 0,878 sebaliknya, jika Economic Value Added (EVA) turun 1\% maka return saham akan turun sebesar 0,878 , hal ini ditunjukkan dari nilai arah koefisien regresi.

Selain itu nilai signifikan Economic Value Added (EVA) adalah 0,023 dimana nilai tersebut lebih kecil dari 0,05. Dan diperoleh nilai t hitung untuk Economic Value Added (EVA) adalah sebesar 2,412 dan t tabel 1,98472 (2,412 > 1,98472) sehingga Ho ditolak artinya: Economic Value Added (EVA) berpengaruh positif dan signifikan terhadap retun saham. hal ini sejalan dengan penelitian Dodd dan Chen (1996), Bacidore et al (1997) dalam Sartono dan Setawan (1996) dan penelitian Rousana (1997).Husniawati (2008), dan Natalia Mangatta dalam Rahayu dan Dana (2016).

Economic Value Added merupakan suatu ukuran kinerja perusahaan yang digunakan mengidentifikasi kegiatan atau proyek yang memberikan pengembalian lebih tinggi dari pada biayabiaya modalnya. Selain itu EVA digunakan sebagai indikator keberhasilan manajemen dalam meningkatkan nilai tambah (value added) bagi perusahaan. Perusahaan yang memiliki Economic Value Added (EVA) yang tinggi cenderung dapat lebih menarik investor, karena semakin tinggi nilai perusahaan maka permintaan investor akan saham perusahaan yang bersangkutan akan semakin meninggkat, sehingga bisa menaikkan harga saham yang kemudian menaikkan return saham. Hasil penelitian ini mengidentifikasi bahwa dengan nilai tambah ekonomis (Economic Value Added) sangat relevan untuk digunakan karena Economic Value Added dapat mengukur prestasi manajamen berdasarkan nilai tambah yang diciptakan oleh perusahaan selama periode tertentu.

Market Value Added (MVA) berpengaruh negatif terhadap return saham. Hal ini ditunjukkan nilai koefisien regresi sebesar -1,442. Apabila Market Value Added (MVA) naik sebesar 1\% maka return saham akan turun sebesar 1,442 sebaliknya, jika Market Value Added (MVA) turun 1\% maka return saham akan naik sebesar 1,442. Selain itu juga dapat dilihat dari nilai signifikan Market Value Added (MVA) sebesar 0,000 yang lebih kecil dari 0,05. Hasil penelitian ini didukung penelitian Husniwati (2008).

Market Value Added (MVA berpengaruh negatif dan signifikan terhadap return Saham,hal ini terjadi jika nilai pasar perusahaan lebih kecil dari pada modal yang di investasikan dapat menurunkan 
minat investor untuk reinvestasi pada perusahaan yang bersangkutan. Dimana nilai pasar adalah harga saham yang terjadi di pasar bursa yang di tentukan oleh pelaku pasar. Market Value Added (MVA) negatif berarti menurunnya nilai modal pemegang saham, dengan rendahnya nilai Market Value Added (MVA) maka perusahaan tidak mampu memberikan keuntungan (return) atau dapat dikatakan pihak manajemen perusahaan tidak mampu meningkatkan kemakmuran bagi para pemegang saham.

Economic Value Added (EVA) dan Market Value Added (MVA) berpengaruh secara simultan dan signifikan terhadap Return Saham pada perusahaan manufaktur yang terdaftar di Bursa Efek Indonesia. Dimana nilai signifikan sebesar 0,000 lebih kecil dari 0,05. Dan diperoleh nilai $\mathrm{F}$ hitung 20,172 yang lebih besar dari pada $\mathrm{F}$ tabel 3,49 (20,172 > 3,49) maka Ho ditolak artinya ; Economic Value Added (EVA) dan Market Value Added (MVA) berpengaruh simultan dan signifikan terhadap Return Saham.

Nilai koefisien korelasi sebesar $77,4 \%$ artinya bahwa terdapat korelasi positif dan kuat antara Economic Value Added (EVA) dan Market Value Added (MVA) dengan return saham.

Nilai koefisien determinasi yang ditunjukkan bahwa nilai R-square sebesar 56,9\% artinya variasi Economic Value Added (EVA) dan Market Value Added (MVA) mampu menjelaskan variasi return saham sebesar 56,9\%. Sedangkan sisanya sebesar 43,1\% dapat dijelaskan oleh variabel lain yang tidak terlibat dalam penelitian ini. Penelitian ini didukung oleh Husniawati (2008) dan Nainggolan dalam Adrias dan Margasari (2015).

\section{KESIMPULAN}

1. Economic Valau Added (EVA) berpengaruh secara parsial dan signifikan terhadap retun saham. pada perusahaan manufaktur yang terdaftar di Bursa Efek Indonesia.

2. Market Value Added (MVA) berpengaruh negatif dan signifikan terhadap return saham. pada perusahaan manufaktur yang terdaftar di Bursa Efek Indonesia.

3. Economic Value Added dan Market Value Added berpengaruh secara simultan dan signifikan terhadap Return saham pada perusahaan manufaktur yang terdaftar di Bursa Efek Indonesia.

\section{DAFTAR PUSTAKA}

Andrias, Sang Sang dan N, Margasari. 2017. Pengaruh Economic Value Added dan Market Value Added terhadap Return Saham pada Perusahaan Manufaktur yang Terdaftar di Bursa Efek Indonesia. Jurnal Manajemen dan Bisnis Indonesia. Universitas Negeri Yokyakarta.

Ang, Robert. 2001. Buku Pintar Pasar Modal lndonesia. Mediasoft.com

Amin Widjaja Tunggal, 2011, Memahami Konsep Economic Value Added (EVA) dan Value Based Management (VBM), Harvarindo.

Brigham, F.E. \& Houston, F.J. 2009. Fundamentals of Financial Management. (Terjemahan Ali Akbar Yulianto). Jakarta: Salemba Empat.

2010 Dasar-Dasar Manajemen Keuangan. Terjemahan Ali Akbar Yulianto.Jakarta: Salemba Empat.

Bacidore, Jeffery M., Boquist, John A., Milbourn, Todd., and Thakor, Anjan V, 1997. The search for the best financial performance measure, Financial Analyst Journal, May- June: 1 1-20.

Dodd, James L., 1996, EVA: A New Panacea Business \& Economic ,Review, July-Sept: 26-27. Dewanto, 1988. Pengaruh EVA Terhadap Harga Saham, Jurnal Ekonomi dan Bisnis Indonesia, Vol.14, No.4, pp. 1 24- 126

Ghozali, Imam. 2018. Aplikasi Analisis Multivariate Dengan Program Spss. Semarang : Badan penerbit Universitas Diponegoro.

Gunawan, Barbara dan R, Putri Hardyani. 2014. Analisis Pengaruh Pengukuran Kinerja Keuangan 
Dalam Memprediksi Return Saham Perusahaan Manufaktur Yang Terdaftar di BEI. Jurnal Akutansi, $\mathrm{Vol}$ 2. Juni. Universitas Muhammadiyah Yokyakarta.

Halim, A. 2003. Analisis Investasi. Edisi Pertama. Jakarta: Salemba Empat.

Hidajat, Natasya Cindy .2018. Pengaruh Retun On Equity ,Earning Per Share Economic Value Added, Dan Market Value Added Terhadap Return Saham Pada Perusahaan Sektor Pertanian di BEI. Jurnal Ekonomi, Vol XXlll. Maret. Universitas Tarumanegara.

Horne V. James dan Jhon M. 1999.Prinsip -Prinsip Manajemen Keuangan (Fundamental Of Financial Management). Edisi 12. Jakarta: Salemba Empat.

Husniawati. 2008. Analisis Pengaruh Economic Value Added, Market Value Added, dan Risiko Sistematik terhadap Return Saham pada Perusahaan Food and Baverages. Jurnal Ekonomi dan Bisnis. Universitas Gunadarma.

Iman Ghozali dan Irwansyah, 2002. Analisis kinerja keuangan perusahaan dengan alat ukur EVA, MVA dan ROA terhadap return saham pada perusahaan manufaktur, jurnal penelitian Akuntansi-Bisnis dan Manajmen Vol 9, No 1 hal 18-33

Kartini dan G,Hermawan.2008. Economic Value Added dan Market Value Added Terhadap Return Saham. Jurnal Keuangan dan Perbankan, Vol 12. September.Yokyakarta 55283.

Kasmir. 2010. Pengantar Manajemen keuangan. Jakarta : Raja Grafindo Persada.

Kountur,Melinda,F dan Victoria,N Untu. 2015. Analisis Economic Value Added Sebagai Alat Pengukuran Perbandingan Kinerja Keuangan Pada Pt.Xl Axiata Dan Pt Indosat. Jurnal Emba,

Maret. Universitas Sam Ratulangi Manado.

Kusumawati, Nugrahini dan N, Hamidah.2017. Economic Value Added Sebagai Alat Ukur Keuangan Perrusahaan. Jurnal Akademika,Vol 15. Februari. Sekolah Tinggi Ilmu Ekonomi Bina Bangsa Serang.

Rahayu, Ni, Made, Putri, Sri. Dan M, Dana. 2016. Pengaruh Eva ,Mva Dan Likuiditas Terhadap Harga Saham Pada Perusahan Food dan Beverages. Jurnal Manajemen Unud,Vol 5. Universitas Udayana.

Rousana M, 1997, Memanfaatkan EVA Untuk Menilai Perusahaan di Pasar Modal Indonesia, Usahawan, No.4, Th.XXVI, April, 1997

Sartono R. Agus dan Kusdhianto Setiawan Kusdhianto, 1999. Adakah Pengaruh EVA Terhadap Nilai Perusahaan dan Kemakmuran Pemegang Saham Pada Perusahaan Publik? Jurnal Ekonomi dan Bisnis Indonesia Vol 14 No.4

Sihaloho, Johan De La Rey, Y Siahaan, P Tarigan dan Supitriyani.2017. Analisis Pengaruh Economic Value Added (EVA) Sebagai Alat Ukur Kinerja Keuangan Pada Pt Unilever Indonesia Yang Terdaftar di BEI. Jurnal Financial, Vol 3. Juni.

Soemarsono S.R. 2005. .Pengantar Akuntansi .Buku satu. Edisi lima. Jakarta: Salemba Empat.

Sidharta Utama,1997. Economic Value Added: Pengukuran Penciptaan Nilai Perusahaan. Usahawan no. 09. Th. XXXVI, September.

Sugiyono. 2009. Metode Penelitian Pendidikan (Pendekatan Kuantitatif, Kualitatif, dan (R\&D). Bandung: Alfabeta. 
Triyono dan Jogiyanto HM, 2000, Hubungan Kandungan Informasi Arus Kas, Komponen Arus Kas, dan Laba Akuntansi dengan Harga atau Return Saham, Jurnal Riset Akuntansi Indonesia, Vol 3, No,1, Januari:54

van Horne, J.C. \& Wachowicz, J.M. 2007. Fundamentals of Financial Management (12th ed.). (Terjemahan Fitriasari, D. \& Kwary, D.A.). Jakarta: Salemba Empat.

Young S. David dan Stephen F. O'Bryne. 2001. EVA\& Manajemen Berdasarkan Nilai, Edisi Pertama. Jakarta: Salemba Empat. 